\title{
Inflammation as a determinant of healing response after coronary stent implantation
}

\author{
Dorota Ochijewicz $^{1} \cdot$ Mariusz Tomaniak $^{1}$ (1) $\cdot$ Grzegorz Opolski $^{1} \cdot$ Janusz Kochman ${ }^{1}$
}

Received: 2 July 2020 / Accepted: 13 October 2020 / Published online: 21 January 2021

(c) The Author(s) 2021

\begin{abstract}
Cardiovascular disease remains the leading cause of death and morbidity worldwide. Inflammation plays an important role in the development of atherosclerosis and is associated with adverse clinical outcomes in patients after percutaneous coronary interventions. Data on stent elements that lead to excessive inflammatory response, proper identification of high-risk patients, prevention and treatment targeting residual inflammatory risk are limited. This review aims to present the role of inflammation in the context of evolving stent technologies and appraise the potential imaging modalities in detection of inflammatory response and anti-inflammatory therapies.
\end{abstract}

Keywords Inflammation $\cdot$ Healing response $\cdot$ Coronary computed tomography angiography $\cdot$ Optical coherence tomography

\section{Introduction}

Abundant lines of evidence, both from clinical and experimental studies, support the hypothesis that inflammation on top of dyslipidemia has an important role in atherothrombosis $[1,2]$. Substantial percentage of patients with atherosclerotic cardiovascular disease with well-controlled low-density lipoprotein cholesterol level and residual inflammatory risk have increased incidence of major adverse cardiac and cerebrovascular accident [3, 4]. Potential molecular link between cholesterol metabolism and inflammation has been recently described through the transcription factor SREBP2 [5]. This suggests the existence of other mechanisms that promote inflammation and new treatment options in this high-risk patient population should be further explored. The Canakinumab Anti-inflammatory Thrombosis Outcomes Study (CANTOS) for the first time provided clinical data showing that targeting inflammation with an antibody against interleukin- $1 \beta$ after myocardial infarction led to a lower incidence of recurrent cardiovascular events than placebo [6]. Available data on healing response after coronary stent implantation in the context of inflammation are scarce.

Mariusz Tomaniak

mariusz.tomaniak@wum.edu.pl

1 1st Department of Cardiology, Medical University of Warsaw, Banacha 1a Str., 02-097 Warsaw, Poland
Stent technology evolved over time and different profiles of clinical complications and healing response were observed. Apart from mechanical factors (underexpansion, fracture) local inflammation can lead to aggressive neointimal proliferation, neoatherosclerosis and in consequence in-stent restenosis. [7] This review highlights the role of local and systemic inflammation, possibilities of invasive and noninvasive imaging and potential treatment strategies after coronary stent implantation.

\section{Local inflammation: should we blame metal, polymer or drug?}

Theoretically, inflammation can occur against any stent component, including the metal, the antiproliferative agent or the polymer. Autopsy and in vivo imaging studies suggest that chronic long-term inflammation and abnormal vessel healing may contribute to adverse stent-related events $[8,9]$ (Fig. 1).

\section{Bare metal stents}

Turning point in the history of interventional cardiology-introduction of bare metal stents (BMS) were developed to prevent occlusion and restenosis following balloon angioplasty [10]. After improvement in stent deployment 


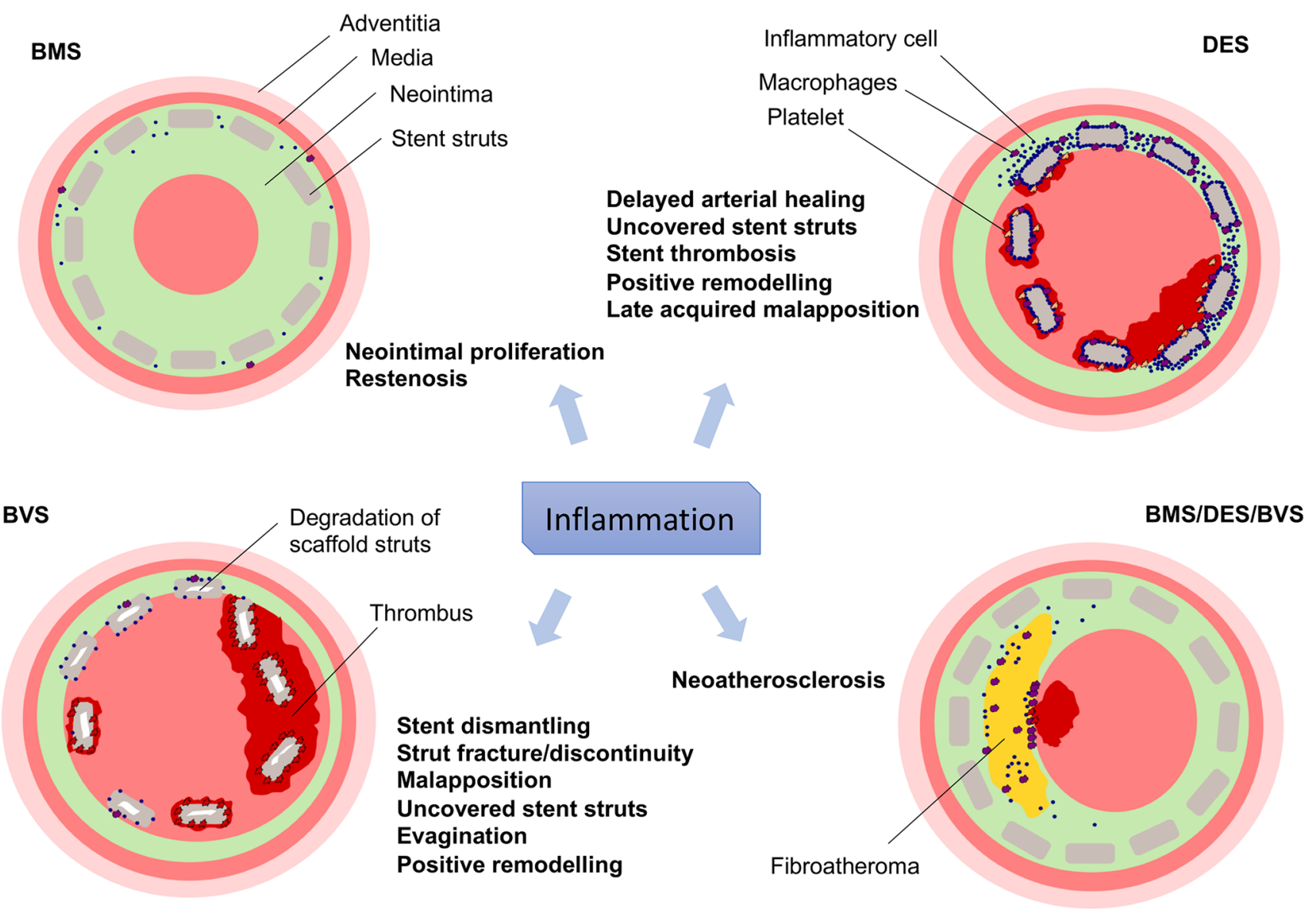

Fig. 1 Adverse events potentially related to inflammation after percutaneous coronary intervention. $B M S$ bare metal stent, $D E S$ drug eluting stent, $B V S$ bioresorbable scaffold

technique and antiplatelet therapy still the risk of neointimal hyperplasia and target lesion revascularization have limited wide utilization of this device [11]. Aberrant vascular smooth muscle cell proliferation and migration is a complex phenomenon with involvement of inflammation after vascular injury [12]. Larger strut thickness have been recognized to impact degree of injury leading to higher inflammation and restenosis [13]. BMS are mostly made from stainless steel, which contains the nickel, chromium, molybdenum and manganese. Although nickel is the most frequent allergen there is no clear evidence that hypersensitivity reaction to metals lead to restenosis after metal stent implantation $[14,15]$. However, metal allergy is frequently observed in patients with recurrence of in-stent restenosis [15-17].

\section{Drug eluting stents}

First generation stainless steel sirolimus-eluting stent (SES) and paclitaxel-eluting stent (PES) were able to substantially reduce in-stent restenosis associated with BMS while increasing the incidence of late stent thrombosis (ST) [18]. Autopsy studies reported delay in arterial healing characterized by persistent fibrin deposition, greater inflammatory reaction with signs of hypersensitivity and delayed reendothelialization when compared with BMS [8, 19, 20]. The most widely accepted mechanism explaining the excess risk of late ST was due to the antiproliferative effect of the drugs released by these devices [8]. Durable polymers used in first generation drug eluting stents (DES): poly(styreneb-isobutylene-b-styrene) for PES and polyethylene-co-vinyl acetate, and poly n-butyl methacrylate for SES are proposed to be associated with chronic inflammation and eosinophils accumulation [21-24] (Table 1). In the SES polymer releases $80 \%$ of the loaded dose of sirolimus in 30 days and the rest by 3 months [25]. The polymer used in PES had a biphasic elution phase of paclitaxel, providing a burst release of 2 days, and subsequently a low-level release over 10 days [26]. In patients with very late stent thrombosis after full release of the drug, histopathological signs of inflammation, delayed-type hypersensitivity reaction and intravascular ultrasound evidence of late acquired malaposition was one 
Table 1 Characteristics of stent type and inflammatory response

\begin{tabular}{|c|c|c|c|c|c|c|c|}
\hline \multirow{2}{*}{$\begin{array}{l}\text { Stent name } \\
\text { (manufacturer) }\end{array}$} & \multirow{2}{*}{$\begin{array}{l}\text { BMS } \\
\text { Bx Velocity } \\
\text { (Medtronic) }\end{array}$} & \multicolumn{2}{|l|}{ 1st DES } & \multicolumn{2}{|l|}{ 2nd DES } & \multirow{2}{*}{$\begin{array}{l}\text { BP-DES } \\
\text { SYNERGY (Bos- } \\
\text { ton Scientific) }\end{array}$} & \multirow{2}{*}{$\begin{array}{l}\text { BVS } \\
\text { Absorb BVS } \\
\text { (Abbott } \\
\text { Vascular) }\end{array}$} \\
\hline & & $\begin{array}{l}\text { CYPHER (John- } \\
\text { son \& Johnson) }\end{array}$ & $\begin{array}{l}\text { TAXUS } \\
\text { Express2 (Boston } \\
\text { Scientific) }\end{array}$ & $\begin{array}{l}\text { XIENCE V } \\
\text { (Abbott Vascu- } \\
\text { lar) }\end{array}$ & $\begin{array}{l}\text { RESOLUTE } \\
\text { (Medtronic) }\end{array}$ & & \\
\hline Drug eluted & - & $\begin{array}{l}\text { Sirolimus }(1.4 \mu \mathrm{g} / \\
\left.\mathrm{mm}^{2}\right)\end{array}$ & $\begin{array}{l}\text { Paclitaxel }(1 \mu \mathrm{g} / \\
\left.\mathrm{mm}^{2}\right)\end{array}$ & $\begin{array}{l}\text { Everolimus } \\
\qquad\left(1 \mu \mathrm{g} / \mathrm{mm}^{2}\right)\end{array}$ & $\begin{array}{l}\text { Zotarolimus } \\
\qquad\left(1 \mu \mathrm{g} / \mathrm{mm}^{2}\right)\end{array}$ & $\begin{array}{l}\text { Everolimus } \\
\qquad\left(1 \mu \mathrm{g} / \mathrm{mm}^{2}\right)\end{array}$ & Everolimus \\
\hline Polymer type & - & $\begin{array}{l}\text { PEVA and } \\
\text { PBMA }\end{array}$ & SIBS & $\begin{array}{l}\text { VDF-HFP and } \\
\text { PBMA }\end{array}$ & $\begin{array}{l}\mathrm{C} 10, \mathrm{C} 19 \text {, and } \\
\text { PVP }\end{array}$ & $\begin{array}{l}\text { Bioresorbable } \\
\text { PLGA (ablu- } \\
\text { minal coating; } \\
\text { bioresorp- } \\
\text { tion kinetics: } \\
4 \text { months) }\end{array}$ & PDLLA \\
\hline $\begin{array}{l}\text { Kinetic of drug } \\
\text { elution }\end{array}$ & - & $\begin{array}{l}80 \% \text { within } \\
30 \text { days; } \\
\text { remainder } \\
\text { released by the } \\
\text { end of } 90 \text { days }\end{array}$ & $\begin{array}{l}<10 \% \text { at } \\
30 \text { days; } 90 \% \\
\text { remains seques- } \\
\text { tered within } \\
\text { the polymer } \\
\text { formulation } \\
\text { without further } \\
\text { measurable } \\
\text { release }\end{array}$ & $\begin{array}{l}80 \% \text { within } \\
30 \text { days; } \\
\text { remainder } \\
\text { released by the } \\
\text { end of } 120 \text { days }\end{array}$ & $\begin{array}{l}70 \% \text { within } \\
30 \text { days; } \\
\text { remainder } \\
\text { released by the } \\
\text { end of } 120 \text { days }\end{array}$ & $\begin{array}{l}50 \% \text { within } \\
2 \text { months and } \\
\text { w100\% at } \\
3 \text { months }\end{array}$ & $\begin{array}{l}80 \% \text { of the } \\
\text { drug is } \\
\text { released in } \\
28 \text { days }\end{array}$ \\
\hline Metal platform & SS & SS & SS & $\mathrm{CoCr}$ & $\mathrm{CoCr}$ & $\mathrm{PtCr}$ & $\overline{-}$ \\
\hline $\begin{array}{l}\text { Strut thickness } \\
{[\mu \mathrm{m})}\end{array}$ & 140 & 140 & 132 & 81 & 91 & 74 & 150 \\
\hline $\begin{array}{l}\text { Signs of inflam- } \\
\text { mation }\end{array}$ & ++ & +++ & +++ & + & + & + & ++ \\
\hline
\end{tabular}

$P B-D E S$ biodegradable polymer-based drug eluting stent, $C 10$ polybutyl methacrylate, $C 19$ polyhexyl methacrylate, polyvinyl acetate, $C o C r$ cobalt chromium alloy, $P B M A$ poly $n$-butyl methacrylate, $P C$ phosphorylcholine, $P E V A$ polyethylene-co-vinyl acetate, $P t C r$ platinum chromium alloy, $P V D F-H F P$ polyvinylidene fluoride co-hexafluoropropylene, $P V P$ polyvinyl pyrrolidone, SIBS poly(styrene-b-isobutylene-b-styrene), $S S$ stainless steel, $P L G A$ poly(D,L-lactidecoglycolide acid), $P D L L A$ poly-D,L-lactide

of the causes of late ST [20]. It is thought that this hypersensitivity reaction occurs as a result of polymer induced inflammation [21,27].

The introduction of second-generation DES significantly reduced target lesion failure (TLF), especially due to its enhanced safety profile, with lower rates of deaths or major adverse cardiovascular events (MACE) [28, 29]. Histological analysis provide evidence of lower incidence of vascular inflammatory response after second generation everolimuseluting stents compared with first generation [30]. Thinner stent struts, more biocompatible, durable polymer (composed of vinylidene fluoride and hexafluoropropylene monomers) releasing a reduced dose of drug compared with firstgeneration DES might be associated with more favorable vascular response [31]. Human autopsy reports showed that the second-generation cobalt-chromium everolimus-eluting stents (CoCr-EES) present lower inflammation response with no hypersensitivity and less fibrin deposition [9]. Efforts to decrease polymer-induced vessel wall inflammation and enhance stent surface endothelialization evolved in development of thinner struts with abluminal bioresorbable polymers so as to modulate directional drug release [32].
In the animal model next-generation bioresorbable polymer DES resulted in lower levels of para-strut inflammation, neointimal foam cell infiltration and neointimal formation at 180 days compared to the permanent polymer DES [33]. Newer-generation DES with thin struts and biodegradable polymers were found to be non-inferior or superior to contemporary durable polymer with respect to composite clinical endpoints [34-36].

The innovation of a special surface morphology for anchoring drugs to the stent-surface to reduce inflammation like polymer-free everolimus-eluting stent (EES) is now under development [37].

\section{Bioresorbable vascular scaffolds}

Permanent nature of metallic struts prevents complete recovery of vascular structure and function with the risk of very late stent failure. Fully bioresorbable vascular scaffold (BVS) were designed to overcome these limitations. The ABSORB BVS (Abbott Vascular) was the most extensively studied device of BVS compared with best in class DES 
Xience (CoCr-EES). Multiple randomized trials and metaanalyses of the ABSORB trials, showed increased rates of target lesion failure and device thrombosis through 5-year follow up [38-40]. Additionally, differences in the vasomotor reactivity were not observed in the favor of BVS [41]. Accordingly, the device was withdrawn from the market in 2017.

There are several presumed mechanisms of the scaffold failure: a less strong mechanical property of bioresorbable materials, in consequence a larger strut thickness and injury, which can predispose to underexpansion/protrusion/ fracture of struts resulting in increased risk of stent thrombosis [42-45]. An ex vivo study has shown greater thrombogenicity and higher inflammation at 28 days after thick strut bioabsorbable EES implantation compared with thin struts biodegradable polymer metallic EES [46]. Histological studies in animal models comparing Absorb BVS and CoCr-EES have shown that inflammation was mild to moderate in Absorb and was greater as compared with DES at 6 to 36 months, although inflammation decreased with time. Both devices exhibited absent or minimal inflammation at 42-month [47]. Histological changes of Absorb dismantling were observed after 12 months with the completed degradation by 36 months [47]. The giant cell infiltration, which is known to be linked to chronic immune responses, has been observed during the resorption process of the scaffolds [48]. However, the prevalence and clinical impact of resorption accompanied by inflammation it is not known.

Studies investigating inflammatory biomarkers: high sensitive C-reactive protein (hsCRP), interleukin-6 (IL6), tumor necrosis factor (TNF) did not show any systemic inflammatory response after BVS placement $[49,50]$.

It seems that the results of Absorb trials should not be applicable to other BVS devices due to different mechanical properties of each bioresorbable material (even amongst poly-L-lactic acid) [51]. Comparison of metallic (Magmaris) and polymeric (Absorb) BVS showed that the magnesium scaffold had significantly less platelet adherence, thrombus deposition, and inflammatory cell adherence in ex vivo study $1 \mathrm{~h}$ after deployment [52].

\section{Neoatherosclerosis}

Chronic inflammation and impaired endothelial healing with increased lipoproteins migration to the sub-endothelial space contribute to neoatherosclerosis development-one of the mechanism for stent restenosis, late and very late ST [53]. Histologically, it is characterized by accumulation of lipid-laden foamy macrophages within the neointima with or without necrotic core and/or calcification [54]. Neoatherosclerosis occurs earlier and more often in 1st generation DES (31\%) compared with BMS (16\%) and increases with time in both platforms [54]. The prevalence of neoatherosclerosis in second-generation CoCr-EES (29\%) was comparable to the first generation DES [9]. In the short period of time, 18 moths follow up, durable and biodegradable polymer DES showed low percentage of neoatherosclerosis $(11.6 \%$ vs. $15.9 \%)$ [55].

Data regarding neoatherosclerosis after BVS implantation is limited and came from optical coherence tomography (OCT) studies with small number of patients. Moriyama et al. confirmed neoatherosclerosis progression with lumen narrowing in all patients in the in-scaffold segments within 5 years compared with no significant signs of atherosclerotic findings in the out-scaffold segments. Conversely, Karanasos et al. observed favorable neointimal healing with development of a signal-rich, low-attenuating tissue layer [56].

The mechanisms underlying the development of neoatherosclerosis are poorly elucidated. The neoatherosclerosis may occur in months to years following percutaneous coronary intervention (PCI), whereas atherosclerosis in native coronary arteries develops over decades. Stent implantation causes vascular injury and local blood flow disturbances associated with endothelial dysfunction which led to activation of inflammatory cells, increase in thrombogenicity and reduced efflux of $\beta$-lipoprotein, which then accumulates within the neointima [57]. Apoptosis of macrophages and smooth muscle cells contribute to the formation of necrotic core and calcification [54]. Immature endothelial cells with increased permeability also promote migration of monocytes [57]. Delayed neointimal healing with incompetent endothelium might promote higher incidence of neoatherosclerosis after 1st generation DES [57]. The underlying native atherosclerotic plaque might as well contribute to the pathogenesis of neoatherosclerosis, however early pathological reports described no anatomical communication with the original atherosclerosis tissue [53].

\section{Optical coherence tomography: signs of inflammation}

Among intravascular imaging methods widely used in clinical practice only OCT generates unprecedented intracoronary images with resolution comparable to histological studies. OCT achieved high diagnostic accuracy (90--95\%) for the classification of coronary plaques: fibroatheroma, fibrocalcific or fibrous plaque [58]. Still the identification of inflammatory cells is much more challenging. Studies aimed at understanding histological correlations between presumed OCT patterns of inflammation after stenting: heterogenous neointima, peri-strut low intensity areas (PLIA) or high-intensity and high-attenuation pattern suggest average diagnostic accuracy-86\%, 30\% and $70 \%$ respectively [59] (Fig. 2). In heterogenous pattern of neointima 


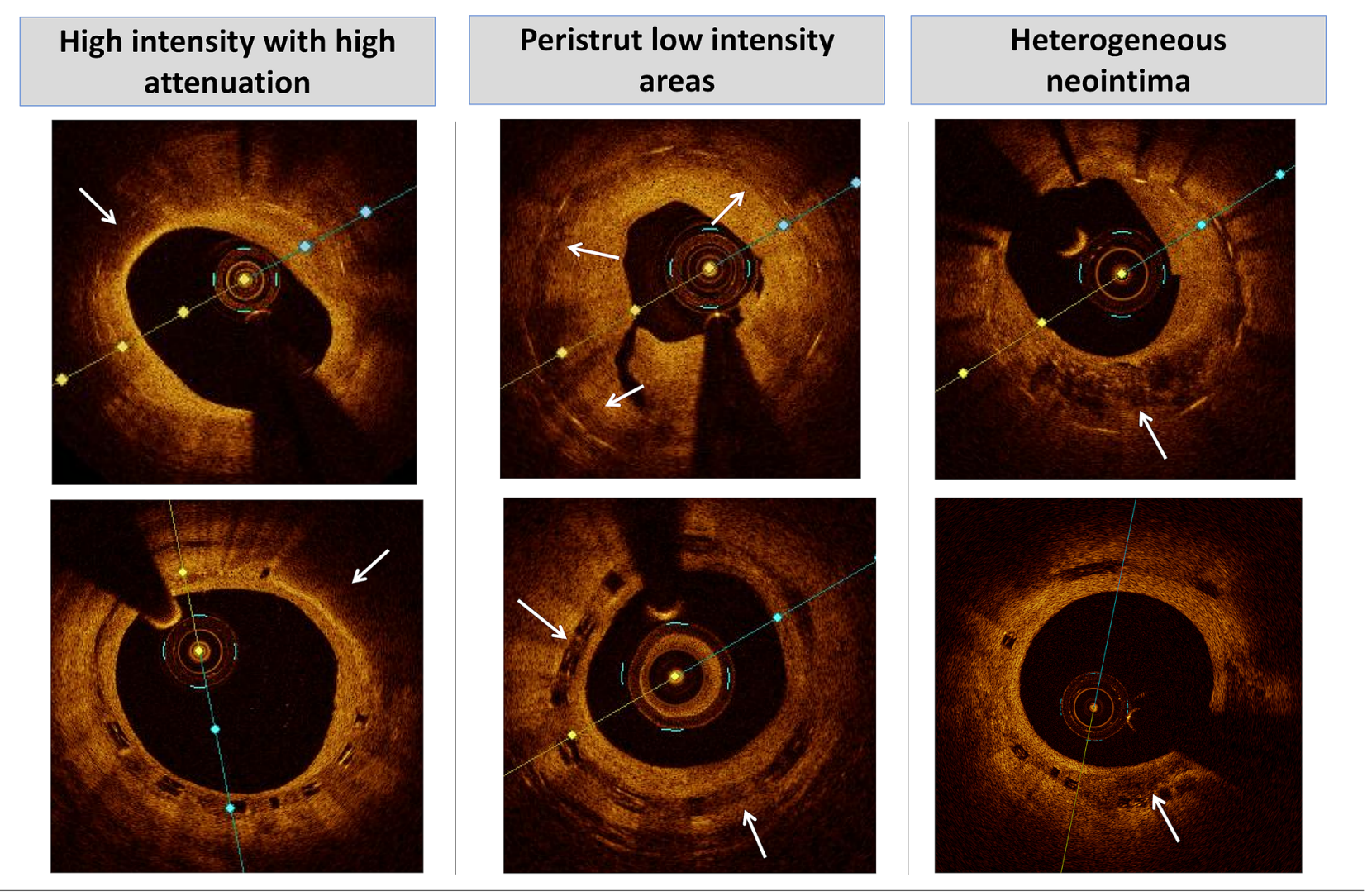

Dominant histopathological diagnosis

\begin{tabular}{|c|c|c|}
\hline $\begin{array}{l}\text { Macrophage } \\
\text { accumulation }\end{array}$ & $\begin{array}{l}\text { Inflammatory reaction } \\
\text { with giant cell and } \\
\text { leukocyte accumulation }\end{array}$ & $\begin{array}{l}\text { Inflammatory reaction with } \\
\text { neointimal giant cell and } \\
\text { leukocyte accumulation }\end{array}$ \\
\hline \multicolumn{3}{|c|}{ Histological differential diagnosis } \\
\hline $\begin{array}{l}\text { - Accumulation of } \\
\text { elastic fibers } \\
\text { - Neointimal calcification } \\
\text { - Neoatherosclerosis }\end{array}$ & $\begin{array}{l}\text { - Peristrut neovascularization } \\
\text { - Peristrut calcification }\end{array}$ & $\begin{array}{l}\text { - Smooth muscle cells in a } \\
\text { proteoglycan- and collagen- } \\
\text { rich tissue } \\
\text { - Neoatherosclerotic foam } \\
\text { cell accumulation } \\
\text { - Cholesterol clefts }\end{array}$ \\
\hline
\end{tabular}

Fig. 2 The optical coherence tomography signs of inflammation with the dominant and differential histopathological findings

histological examination revealed inflammation with neointimal giant cell accumulation (34\%), leukocyte accumulation (29\%), neoatherosclerotic foam cell accumulation (12\%) or cholesterol clefts (11\%), healthy neointima (12\%), and fibrin accumulation (3\%) [59]. PLIA defined as a circumscribed low-intensity area surrounding struts showed a number of different matching histopathological components, including inflammatory reaction characterized by peristrut giant cell accumulation $(23 \%)$ or peristrut leukocyte accumulation (13\%), peristrut neovascularization (36\%) and peristrut calcification (18\%). High-intensity, high-attenuation pattern revealed a predominance of foam cell accumulation (68\%), superficial elastic fibers without foamy macrophages (12\%), and neointimal calcification (11\%). Despite wide variety of 
histological differential diagnoses the aforementioned patterns have clinical significance. Observational OCT studies of patients receiving DES showed that presence of heterogenous neointima was linked with major adverse cardiac events over a median 31-month follow-up [60]. The presence of PLIA was associated with an increased rate of target lesion revascularization after everolimus-eluting stent implantation [61]. The foamy macrophage clusters are the earliest feature of neoatherosclerosis [53]. Superficial location of macrophages with co-presence of minimal lumen area $<4 \mathrm{~mm}^{2}$ and fibrous cap thickness $<75 \mu \mathrm{m}$ are validated features of plaque vulnerability [62]. In patients with very late ST macrophage infiltration was more frequent within ruptured plaques whereas calcifications were more common in frames with intact fibrous cap [63]. However, the ability to identify macrophages in optical coherence tomography is limited [64]. Bright spots were correlated with a variety of plaque components that cause sharp changes in the index of refraction (macrophages, cellular fibrous tissue, interfaces between calcium and fibrous tissue, calcium and lipids, fibrous cap and lipid pool) [64]. Additionally, large pools of lipid-rich macrophages corresponded to dark regions [64]. Novel intravascular modality e.g. micro-OCT (mOCT), which offers an axial resolution of $1 \mu \mathrm{m}$, may visualize cells more precisely [65].

To explore the issue of proper inflammation cells visualization further investment in technology of greater accuracy must continue. Beyond the morphological characteristics we also need additional physiological features like activity of immune cells, endothelial shear stress, state of endothelial function and hypercoagulation.

\section{Non-invasive imaging}

Clinical applicability of non-invasive imaging modalities in secondary prevention to detect residual inflammatory risk remains limited [66]. Hybrid methods like positron emission tomography/computed tomography (PET/CT) and positron emission tomography/magnetic resonance (PET/MR) coregister PET images with CT or MR anatomical data [67]. 18 -fluorodeoxyglucose (18F-FDG) uptake by metabolically active cells (e.g. macrophages) can detect inflammation and assess the efficacy of statin therapy [68]. Although nuclear imaging appears to provide a good solution for the imaging of coronary inflammation, these methods remain expensive, with limited clinical availability and high radiation exposure. Nowadays, the most promising data can be obtained from coronary computed tomography angiography (CCTA). Based on observation that coronary artery inflammation inhibits adipogenesis in adjacent perivascular fat, a novel imaging biomarker-the perivascular fat attenuation index (FAI) - has been proposed to capture coronary inflammation by mapping spatial changes of perivascular fat attenuation $[69,70]$. The FAI has excellent sensitivity and specificity for detecting inflammation as assessed by tissue uptake of 18F-FDG in PET [70]. High perivascular FAI values (cutoff $\geq-70,1 \mathrm{HU}$ ) were an indicator of increased all-cause and cardiac mortality in two large prospective cohorts of patients undergoing clinically indicated CCTA [69]. FAI could facilitate identification of high-risk individuals, before structural changes of the coronary wall are visible. Additionally CCTA can detect high risk plaque (HRP) features like: the napkinring sign, positive remodeling, low attenuation plaque and spotty calcification that are all associated with a high risk of acute cardiovascular events [71]. The combination of HRP and perivascular FAI can better guide the novel therapies for residual inflammatory risk.

\section{Systemic inflammation}

Patients with increased inflammatory status undergoing PCI are at high-risk of adverse clinical outcomes [4, 72, 73]. Both pre- and post-PCI increased C-reactive protein (CRP) and hsCRP level was a prognostic indicator for subsequent cardiac events $[4,74,75]$.

Several different pro-inflammatory cytokines such as IL-6, matrix metalloproteinase-9 (MMP-9), and tumor necrosis factor- $\alpha$ (TNF- $\alpha$ ) are each associated with coronary heart disease risk independent of conventional risk factors [76]. Even after low density lipoprotein (LDL) cholesterol level reduction by proprotein convertase subtilisin/kexin type 9 (PCSK9) inflammatory status is a strong predictor of adverse clinical results [77, 78]. Statins were also found to have greatest efficacy in the presence of vascular inflammation and reduce CRP level largely independent of LDL reduction $[79,80]$. The complex interaction between modest elevations in plasma inflammatory biomarkers, systemic and local factors contributing to development of vulnerable plaques are not yet completely understood. Therefore, it has been hypothesized that targeting different inflammatory pathways might have efficacy in the treatment and prevention of cardiovascular disease.

\section{Therapies for residual inflammation}

The pleiotropic anti-inflammatory and immunomodulatory effect of statins is supposed to provide greater survival benefits in the population with chronic inflammation in addition to its LDL-C lowering effect [80-82]. Statins regulate the functions of $\mathrm{T}$ and $\mathrm{B}$ lymphocytes, dendritic cells, natural killer cells, reduce the production of inflammatory markers (CRP, TNF, IL-1, IL-6) and reduce the incidence of major cardiovascular events in patients with elevated 


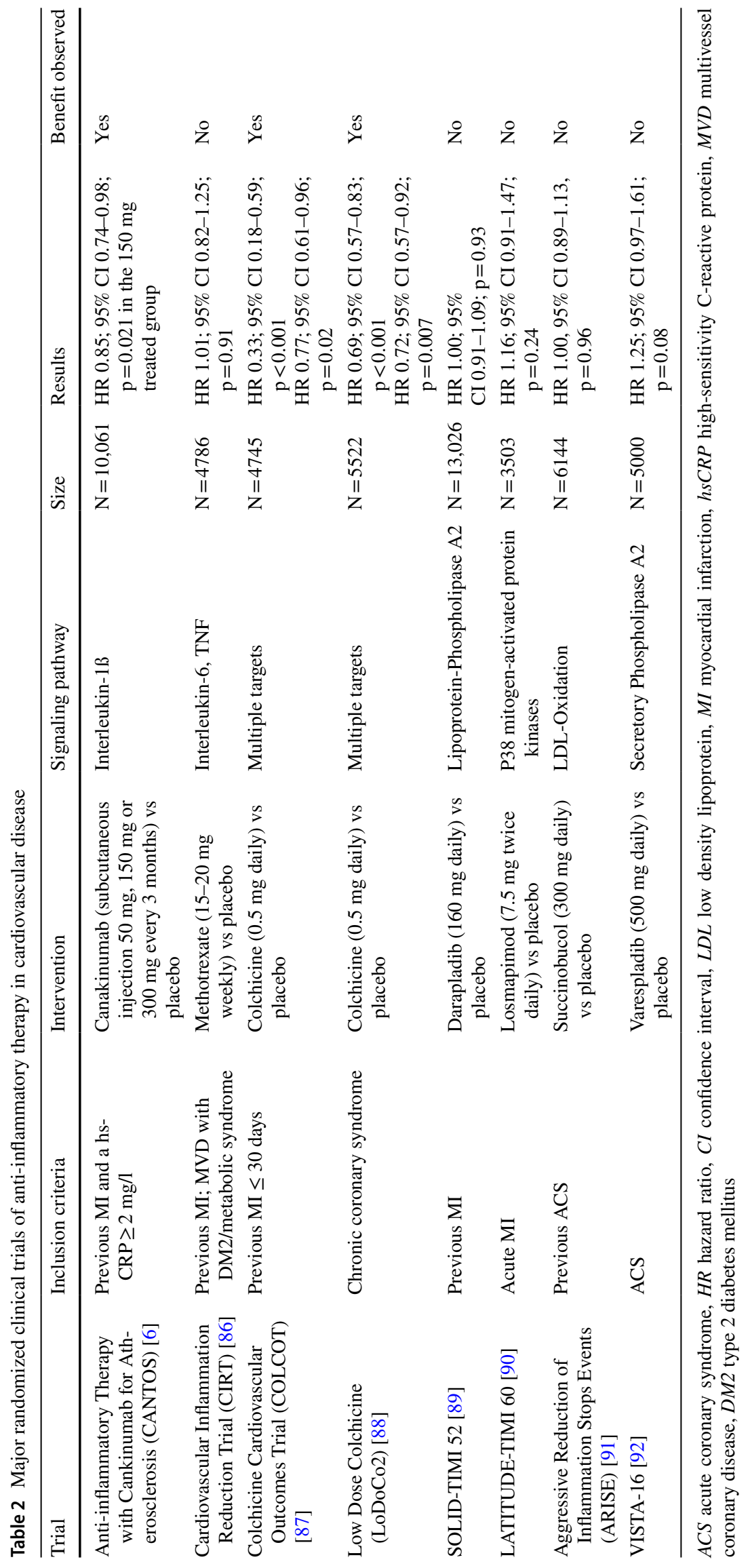


high-sensitivity CRP levels but without hyperlipidemia [83-85]. Despite intensive lipid-lowering therapy patients with coronary disease and residual inflammatory response remain at high risk for acute cardiovascular events [77]. Various novel anti-inflammatory agents have been investigated in preventing atherosclerotic complications (Table 2). To date, most promising results have been obtained from clinical trials involving canakinumab-targeted interleukin13 in patients with previous MI (myocardial infarction) and a high sensitivity CRP $\geq 2 \mathrm{mg} / \mathrm{l}$. The primary endpoint of the study was the first occurrence of myocardial infarction, non-fatal stroke or cardiovascular death. Canakinumab administration have translated to a $15 \%$ relative risk reduction for MACE with concomitant increased rates of infection [6]. In the CIRT trial low-dose methotrexate did not reduce cardiovascular events and levels of interleukin-1 $\beta$, interleukin-6 or CRP than placebo. However the study included all patients with previous MI or multivessel coronary disease regardless of residual inflammatory risk [86]. Recently published COLCOT and LoDoCo2 studies investigated the colchicine-inhibitor of tubulin polymerization, microtubule generation and possibly modifier of molecules adhesion, inflammatory chemokines and the inflammasome. In patients within 30 days after myocardial infarction and in patients with chronic coronary syndrome administration of colchicine significantly decreased ischemic cardiovascular events in comparison to placebo $[87,88]$. Given the multifarious nature of inflammation in atherosclerotic processes, there is a clear need for future novel and safe therapies in patients found to have persistent residual inflammatory risk.

\section{Conclusions}

Inflammatory responses after percutaneous coronary intervention lead to abnormal neointimal healing and increased risk of adverse clinical outcomes. Neither imaging nor other diagnostic modalities are available to accurately detect inflammation in coronary arteries treated with stent implantation to date. The perivascular fat attenuation index assessed by CCTA appears the most promising noninvasive modality to detect residual inflammatory risk. OCT is most useful intravascular imaging in determining surrogate imaging parameters of inflammation. Residual inflammation, considered as a modifiable pathogenic factor, remains still not adequately addressed for cardiovascular risk modification.

Funding The article was produced by and under the sole responsibility of the authors without any financial support.

\section{Compliance with ethical standards}

Conflicts of interest The authors have no conflicts of interest do declare.

Open Access This article is licensed under a Creative Commons Attribution 4.0 International License, which permits use, sharing, adaptation, distribution and reproduction in any medium or format, as long as you give appropriate credit to the original author(s) and the source, provide a link to the Creative Commons licence, and indicate if changes were made. The images or other third party material in this article are included in the article's Creative Commons licence, unless indicated otherwise in a credit line to the material. If material is not included in the article's Creative Commons licence and your intended use is not permitted by statutory regulation or exceeds the permitted use, you will need to obtain permission directly from the copyright holder. To view a copy of this licence, visit http://creativecommons.org/licenses/by/4.0/.

\section{References}

1. Hansson GK (2005) Inflammation, atherosclerosis, and coronary artery disease. N Engl J Med 352:1685-1695

2. Libby P, Ridker PM, Hansson GK (2009) Inflammation in atherosclerosis: from pathophysiology to practice. J Am Coll Cardiol 54:2129-2138

3. Guedeney P, Claessen BE, Kalkman DN, Aquino M, Sorrentino S, Giustino G et al (2019) Residual inflammatory risk in patients with low LDL cholesterol levels undergoing percutaneous coronary intervention. J Am Coll Cardiol 73:2401-2409

4. Kalkman DN, Aquino M, Claessen BE, Baber U, Guedeney P, Sorrentino $S$ et al (2018) Residual inflammatory risk and the impact on clinical outcomes in patients after percutaneous coronary interventions. Eur Heart J 39:4101-4108

5. Gu Q, Yang X, Lv J, Zhang J, Xia B, Kim JD et al (2019) AIBPmediated cholesterol efflux instructs hematopoietic stem and progenitor cell fate. Science 363:1085-1088

6. Ridker PM, Everett BM, Thuren T, MacFadyen JG, Chang WH, Ballantyne C et al (2017) Antiinflammatory therapy with canakinumab for atherosclerotic disease. N Engl J Med 377:1119-1131

7. Shlofmitz E, Iantorno M, Waksman R (2019) Restenosis of drugeluting stents. Circ Cardiovasc Interv 12:26

8. Joner M, Finn AV, Farb A, Mont EK, Kolodgie FD, Ladich E et al (2006) Pathology of drug-eluting stents in humans: delayed healing and late thrombotic risk. J Am Coll Cardiol 48:193-202

9. Otsuka F, Vorpahl M, Nakano M, Foerst J, Newell JB, Sakakura $\mathrm{K}$ et al (2014) Pathology of second-generation everolimus-eluting stents versus first-generation sirolimus- and paclitaxel-eluting stents in humans. Circulation 129:211-223

10. Sigwart U, Puel J, Mirkovitch V, Joffre F, Kappenberger L (1987) Intravascular stents to prevent occlusion and restenosis after transluminal angioplasty. N Engl J Med 316:701-706

11. Kirtane AJ, Gupta A, Iyengar S, Moses JW, Leon MB, Applegate $R$ et al (2009) Safety and efficacy of drug-eluting and bare metal stents: comprehensive meta-analysis of randomized trials and observational studies. Circulation 119:3198-3206

12. Farb A, Sangiorgi G, Carter AJ, Walley VM, Edwards WD, Schwartz RS et al (1999) Pathology of acute and chronic coronary stenting in humans. Circulation 99:44-52

13. Foin N, Lee RD, Torii R, Guitierrez-Chico JL, Mattesini A, Nijjer $S$ et al (2014) Impact of stent strut design in metallic stents and biodegradable scaffolds. Int J Cardiol 177:800-808 
14. Hillen U, Haude M, Erbel R, Goos M (2002) Evaluation of metal allergies in patients with coronary stents. Contact Dermat 47:353-356

15. Iijima R, Ikari Y, Amiya E, Tanimoto S, Nakazawa G, Kyono H et al (2005) The impact of metallic allergy on stent implantation: metal allergy and recurrence of in-stent restenosis. Int J Cardiol 104:319-325

16. Koster R, Vieluf D, Kiehn M, Sommerauer M, Kahler J, Baldus S et al (2000) Nickel and molybdenum contact allergies in patients with coronary in-stent restenosis. Lancet 356:1895-1897

17. Saito T, Hokimoto S, Oshima S, Noda K, Kojyo Y, Matsunaga $\mathrm{K}$ (2009) Metal allergic reaction in chronic refractory in-stent restenosis. Cardiovasc Revasc Med 10:17-22

18. Tada T, Byrne RA, Simunovic I, King LA, Cassese S, Joner M et al (2013) Risk of stent thrombosis among bare-metal stents, first-generation drug-eluting stents, and second-generation drugeluting stents: results from a registry of 18,334 patients. JACC Cardiovasc Interv 6:1267-1274

19. Nakazawa G, Finn AV, Vorpahl M, Ladich ER, Kolodgie FD, Virmani R (2011) Coronary responses and differential mechanisms of late stent thrombosis attributed to first-generation sirolimus- and paclitaxel-eluting stents. J Am Coll Cardiol 57:390-398

20. Cook S, Ladich E, Nakazawa G, Eshtehardi P, Neidhart M, Vogel R et al (2009) Correlation of intravascular ultrasound findings with histopathological analysis of thrombus aspirates in patients with very late drug-eluting stent thrombosis. Circulation 120:391-399

21. Virmani R, Guagliumi G, Farb A, Musumeci G, Grieco N, Motta $\mathrm{T}$ et al (2004) Localized hypersensitivity and late coronary thrombosis secondary to a sirolimus-eluting stent: should we be cautious? Circulation 109:701-705

22. Stone GW, Moses JW, Ellis SG, Schofer J, Dawkins KD, Morice MC et al (2007) Safety and efficacy of sirolimus- and paclitaxeleluting coronary stents. N Engl J Med 356:998-1008

23. Finn AV, Kolodgie FD, Harnek J, Guerrero LJ, Acampado E, Tefera K et al (2005) Differential response of delayed healing and persistent inflammation at sites of overlapping sirolimus- or paclitaxel-eluting stents. Circulation 112:270-278

24. Wilson GJ, Nakazawa G, Schwartz RS, Huibregtse B, Poff B, Herbst TJ et al (2009) Comparison of inflammatory response after implantation of sirolimus- and paclitaxel-eluting stents in porcine coronary arteries. Circulation 120:141-149

25. Morice MC, Serruys PW, Sousa JE, Fajadet J, Ban Hayashi E, Perin $\mathrm{M}$ et al (2002) A randomized comparison of a sirolimuseluting stent with a standard stent for coronary revascularization. N Engl J Med 346:1773-1780

26. Serruys PW, Kutryk MJ, Ong AT (2006) Coronary-artery stents. N Engl J Med 354:483-495

27. Nebeker JR, Virmani R, Bennett CL, Hoffman JM, Samore MH, Alvarez J et al (2006) Hypersensitivity cases associated with drug-eluting coronary stents: a review of available cases from the Research on Adverse Drug Events and Reports (RADAR) project. J Am Coll Cardiol 47:175-181

28. Brener SJ, Kereiakes DJ, Simonton CA, Rizvi A, Newman W, Mastali K et al (2013) Everolimus-eluting stents in patients undergoing percutaneous coronary intervention: final 3-year results of the Clinical Evaluation of the XIENCE V Everolimus Eluting Coronary Stent System in the Treatment of Subjects With de Novo Native Coronary Artery Lesions trial. Am Heart J 166:1035-1042

29. Gada H, Kirtane AJ, Newman W, Sanz M, Hermiller JB, Mahaffey KW et al (2013) 5-year results of a randomized comparison of XIENCE V everolimus-eluting and TAXUS paclitaxel-eluting stents: final results from the SPIRIT III trial (clinical evaluation of the XIENCE V everolimus eluting coronary stent system in the treatment of patients with de novo native coronary artery lesions). JACC Cardiovasc Interv 6:1263-1266
30. Yeh JS, Oh SJ, Hsueh CM (2016) Frequency of vascular inflammation and impact on neointimal proliferation of drug eluting stents in porcine coronary arteries. Acta Cardiol Sin 32:570-577

31. Ino $\mathrm{Y}$, Kubo $\mathrm{T}$, Tanaka A, Liu Y, Tanimoto $\mathrm{T}$, Kitabata $\mathrm{H}$ et al (2015) Comparison of vascular response between everolimuseluting stent and bare metal stent implantation in ST-segment elevation myocardial infarction assessed by optical coherence tomography. Eur Heart J Cardiovasc Imaging 16:513-520

32. Meredith IT, Verheye S, Weissman NJ, Barragan P, Scott D, Valdes Chavarri M et al (2013) Six-month IVUS and two-year clinical outcomes in the EVOLVE FHU trial: a randomised evaluation of a novel bioabsorbable polymer-coated, everolimus-eluting stent. EuroIntervention 9:308-315

33. Wilson GJ, McGregor J, Conditt G, Shibuya M, Sushkova N, Eppihimer MJ et al (2018) Impact of bioresorbable versus permanent polymer on longterm vessel wall inflammation and healing: a comparative drug-eluting stent experimental study. EuroIntervention 13:1670-1679

34. Iglesias JF, Muller O, Heg D, Roffi M, Kurz DJ, Moarof I et al (2019) Biodegradable polymer sirolimus-eluting stents versus durable polymer everolimus-eluting stents in patients with ST-segment elevation myocardial infarction (BIOSTEMI): a single-blind, prospective, randomised superiority trial. Lancet 394:1243-1253

35. Kereiakes DJ, Windecker S, Jobe RL, Mehta SR, Sarembock IJ, Feldman RL et al (2019) Clinical outcomes following implantation of thin-strut, bioabsorbable polymer-coated, everolimuseluting SYNERGY stents. Circ Cardiovasc Interv 12:27

36. Picard F, Pighi M, de Hemptinne Q, Airaksinen J, Vinco G, de Pommereau A et al (2019) Comparison of the biodegradable polymer everolimus-eluting stent with contemporary drug-eluting stents: a systematic review and meta-analysis. Int J Cardiol 278:51-56

37. Bae IH, Jeong MH, Lim KS, Park DS, Shim JW, Park JK et al (2018) Novel polymer-free everolimus-eluting stent fabricated using femtosecond laser improves re-endothelialization and antiinflammation. Sci Rep 8:018-25629

38. Ali ZA, Gao R, Kimura T, Onuma Y, Kereiakes DJ, Ellis SG et al (2018) Three-year outcomes with the absorb bioresorbable scaffold: individual-patient-data meta-analysis from the ABSORB randomized trials. Circulation 137:464-479

39. Stone GW, Kimura T, Gao R, Kereiakes DJ, Ellis SG, Onuma Y et al (2019) Time-varying outcomes with the absorb bioresorbable vascular scaffold during 5-year follow-up: a systematic metaanalysis and individual patient data pooled study. JAMA Cardiol 4:1261-1269

40. Kereiakes DJ, Ellis SG, Metzger DC, Caputo RP, Rizik DG, Teirstein PS et al (2019) Clinical outcomes prior to and following complete everolimus-eluting bioresorbable scaffold resorption: five-year follow-up from the ABSORB III trial. Circulation 25:042584

41. Dudek D, Rzeszutko L, Onuma Y, Sotomi Y, Depukat R, Veldhof $S$ et al (2017) Vasomotor response to nitroglycerine over 5 years follow-up after everolimus-eluting bioresorbable scaffold implantation. JACC Cardiovasc Interv 10:786-795

42. Bangalore S, Bezerra HG, Rizik DG, Armstrong EJ, Samuels B, Naidu SS et al (2017) The state of the absorb bioresorbable scaffold: consensus from an expert panel. JACC Cardiovasc Interv 10:2349-2359

43. Puricel S, Cuculi F, Weissner M, Schmermund A, Jamshidi P, Nyffenegger T et al (2016) Bioresorbable coronary scaffold thrombosis: multicenter comprehensive analysis of clinical presentation, mechanisms, and predictors. J Am Coll Cardiol 67:921-931

44. Yamaji K, Ueki Y, Souteyrand G, Daemen J, Wiebe J, Nef H et al (2017) Mechanisms of very late bioresorbable scaffold thrombosis: the INVEST registry. J Am Coll Cardiol 70:2330-2344 
45. Kereiakes DJ, Onuma Y, Serruys PW, Stone GW (2016) Bioresorbable vascular scaffolds for coronary revascularization. Circulation 134:168-182

46. Koppara T, Cheng Q, Yahagi K, Mori H, Sanchez OD, Feygin J et al (2015) Thrombogenicity and early vascular healing response in metallic biodegradable polymer-based and fully bioabsorbable drug-eluting stents. Circ Cardiovasc Interv 8:002427

47. Otsuka F, Pacheco E, Perkins LE, Lane JP, Wang Q, Kamberi $M$ et al (2014) Long-term safety of an everolimus-eluting bioresorbable vascular scaffold and the cobalt-chromium XIENCE V stent in a porcine coronary artery model. Circ Cardiovasc Interv 7:330-342

48. Kraak RP, de Boer HH, Elias J, Ambarus CA, van der Wal AC, de Winter RJ et al (2015) Coronary artery vessel healing pattern, short and long term, after implantation of the everolimus-eluting bioresorbable vascular scaffold. J Am Heart Assoc 4:002551

49. Rampat R, Williams T, Mayo T, Mengozzi M, Ghezzi P, HildickSmith D et al (2019) Association between inflammatory biomarkers and neointimal response following elective implantation of the ABSORB bioresorbable vascular scaffold. Coron Artery Dis 30:183-187

50. Kozel M, Kocka V, Lisa L, Budesinsky T, Tousek P (2019) Immune-inflammatory response after bioresorbable vascular scaffold implantation in patients with acute myocardial infarction with ST elevation in a long-term perspective. Heart Vessels 34:557-563

51. Katagiri Y, Serruys PW, Asano T, Miyazaki Y, Chichareon P, Modolo R et al (2019) How does the failure of Absorb apply to the other bioresorbable scaffolds? An expert review of first-in-man and pivotal trials. EuroIntervention 15:116-123

52. Waksman R, Lipinski MJ, Acampado E, Cheng Q, Adams L, Torii $S$ et al (2017) Comparison of acute thrombogenicity for metallic and polymeric bioabsorbable scaffolds: magmaris versus absorb in a porcine arteriovenous shunt model. Circ Cardiovasc Interv 10:004762

53. Otsuka F, Byrne RA, Yahagi K, Mori H, Ladich E, Fowler DR et al (2015) Neoatherosclerosis: overview of histopathologic findings and implications for intravascular imaging assessment. Eur Heart J 36:2147-2159

54. Nakazawa G, Otsuka F, Nakano M, Vorpahl M, Yazdani SK, Ladich E et al (2011) The pathology of neoatherosclerosis in human coronary implants bare-metal and drug-eluting stents. J Am Coll Cardiol 57:1314-1322

55. Guagliumi G, Shimamura K, Sirbu V, Garbo R, Boccuzzi G, Vassileva A et al (2018) Temporal course of vascular healing and neoatherosclerosis after implantation of durable- or biodegradablepolymer drug-eluting stents. Eur Heart J 39:2448-2456

56. Karanasos A, Simsek C, Gnanadesigan M, van Ditzhuijzen NS, Freire R, Dijkstra J et al (2014) OCT assessment of the long-term vascular healing response 5 years after everolimus-eluting bioresorbable vascular scaffold. J Am Coll Cardiol 64:2343-2356

57. Otsuka F, Finn AV, Yazdani SK, Nakano M, Kolodgie FD, Virmani R (2012) The importance of the endothelium in atherothrombosis and coronary stenting. Nat Rev Cardiol 9:439-453

58. Shimokado A, Kubo T, Matsuo Y, Ino Y, Shiono Y, Shimamura $\mathrm{K}$ et al (2019) Imaging assessment and accuracy in coronary artery autopsy: comparison of frequency-domain optical coherence tomography with intravascular ultrasound and histology. Int J Cardiovasc Imaging 7:019-01639

59. Lutter C, Mori H, Yahagi K, Ladich E, Joner M, Kutys R et al (2016) Histopathological differential diagnosis of optical coherence tomographic image interpretation after stenting. JACC Cardiovasc Interv 9:2511-2523

60. Kim JS, Lee JH, Shin DH, Kim BK, Ko YG, Choi D et al (2014) Long-term outcomes of neointimal hyperplasia without neoatherosclerosis after drug-eluting stent implantation. JACC Cardiovasc Imaging 7:788-795

61. Kuroda K, Otake H, Shinke T, Toba T, Kuroda M, Takahashi H et al (2018) Peri-strut low-intensity area assessed by mid-term follow-up optical coherence tomography may predict target lesion revascularization after everolimus-eluting stent implantation. EuroIntervention 26:17-01134

62. Prati F, Gatto L, Romagnoli E, Limbruno U, Fineschi M, Marco V et al (2018) In vivo vulnerability grading system of plaques causing acute coronary syndromes: an intravascular imaging study. Int J Cardiol 269:350-355

63. Joner M, Koppara T, Byrne RA, Castellanos MI, Lewerich J, Novotny J et al (2018) Neoatherosclerosis in patients with coronary stent thrombosis: findings from optical coherence tomography imaging (a report of the PRESTIGE Consortium). JACC Cardiovasc Interv 11:1340-1350

64. Phipps JE, Vela D, Hoyt T, Halaney DL, Mancuso JJ, Buja LM et al (2015) Macrophages and intravascular OCT bright spots: a quantitative study. JACC Cardiovasc Imaging 8:63-72

65. Liu L, Gardecki JA, Nadkarni SK, Toussaint JD, Yagi Y, Bouma BE et al (2011) Imaging the subcellular structure of human coronary atherosclerosis using micro-optical coherence tomography. Nat Med 17:1010-1014

66. Antoniades C, Antonopoulos AS, Deanfield J (2020) Imaging residual inflammatory cardiovascular risk. Eur Heart J 41:748-758

67. Goel S, Miller A, Agarwal C, Zakin E, Acholonu M, Gidwani U et al (2015) Imaging modalities to identity inflammation in an atherosclerotic plaque. Radiol Res Pract 410967:20

68. Tahara N, Kai H, Ishibashi M, Nakaura H, Kaida H, Baba K et al (2006) Simvastatin attenuates plaque inflammation: evaluation by fluorodeoxyglucose positron emission tomography. J Am Coll Cardiol 48:1825-1831

69. Oikonomou EK, Marwan M, Desai MY, Mancio J, Alashi A, Hutt Centeno E et al (2018) Non-invasive detection of coronary inflammation using computed tomography and prediction of residual cardiovascular risk (the CRISP CT study): a post hoc analysis of prospective outcome data. Lancet 392:929-939

70. Antonopoulos AS, Sanna F, Sabharwal N, Thomas S, Oikonomou EK, Herdman L et al (2017) Detecting human coronary inflammation by imaging perivascular fat. Sci Transl Med. https://doi. org/10.1126/scitranslmed.aal2658

71. Maurovich-Horvat P, Ferencik M, Voros S, Merkely B, Hoffmann U (2014) Comprehensive plaque assessment by coronary CT angiography. Nat Rev Cardiol 11:390-402

72. Arroyo-Espliguero R, Avanzas P, Cosin-Sales J, Aldama G, Pizzi C, Kaski JC (2004) C-reactive protein elevation and disease activity in patients with coronary artery disease. Eur Heart J 25:401-408

73. Mincu RI, Janosi RA, Vinereanu D, Rassaf T, Totzeck M (2017) Preprocedural C-reactive protein predicts outcomes after primary percutaneous coronary intervention in patients with ST-elevation myocardial infarction a systematic meta-analysis. Sci Rep 7:1-10

74. de Winter RJ, Heyde GS, Koch KT, Fischer J, van Straalen JP, Bax M et al (2002) The prognostic value of pre-procedural plasma $\mathrm{C}$-reactive protein in patients undergoing elective coronary angioplasty. Eur Heart J 23:960-966

75. Caixeta AM, Brito FS Jr, Costa MA, Serrano CV Jr, Petriz JL, Da Luz PL (2007) Enhanced inflammatory response to coronary stenting marks the development of clinically relevant restenosis. Catheter Cardiovasc Interv 69:500-507

76. Kaptoge S, Seshasai SR, Gao P, Freitag DF, Butterworth AS, Borglykke A et al (2014) Inflammatory cytokines and risk of coronary heart disease: new prospective study and updated meta-analysis. Eur Heart J 35:578-589 
77. Bohula EA, Giugliano RP, Leiter LA, Verma S, Park JG, Sever PS et al (2018) Inflammatory and cholesterol risk in the FOURIER trial. Circulation 138:131-140

78. Pradhan AD, Aday AW, Rose LM, Ridker PM (2018) Residual inflammatory risk on treatment with PCSK9 inhibition and statin therapy. Circulation 138:141-149

79. Chu AY, Guilianini F, Barratt BJ, Nyberg F, Chasman DI, Ridker PM (2012) Pharmacogenetic determinants of statin-induced reductions in C-reactive protein. Circ Cardiovasc Genet 5:58-65

80. Ridker PM, Danielson E, Fonseca FA, Genest J, Gotto AM Jr, Kastelein JJ et al (2009) Reduction in C-reactive protein and LDL cholesterol and cardiovascular event rates after initiation of rosuvastatin: a prospective study of the JUPITER trial. Lancet 373:1175-1182

81. Ajala ON, Demler OV, Liu Y, Farukhi Z, Adelman SJ, Collins HL et al (2020) Anti-inflammatory HDL function, incident cardiovascular events, and mortality: a secondary analysis of the JUPITER randomized clinical trial. J Am Heart Assoc 9:15

82. Li GM, Zhao J, Li B, Zhang XF, Ma JX, Ma XL et al (2018) The anti-inflammatory effects of statins on patients with rheumatoid arthritis: a systemic review and meta-analysis of 15 randomized controlled trials. Autoimmun Rev 17:215-225

83. Ridker PM, Danielson E, Fonseca FA, Genest J, Gotto AM Jr, Kastelein JJ et al (2008) Rosuvastatin to prevent vascular events in men and women with elevated C-reactive protein. N Engl J Med 359:2195-2207

84. Tabrizi R, Tamtaji OR, Mirhosseini N, Lankarani KB, Akbari M, Dadgostar E et al (2019) The effects of statin use on inflammatory markers among patients with metabolic syndrome and related disorders: a systematic review and meta-analysis of randomized controlled trials. Pharmacol Res 141:85-103

85. Shahbaz SK, Sadeghi M, Koushki K, Penson PE, Sahebkar A (2019) Regulatory T cells: possible mediators for the anti-inflammatory action of statins. Pharmacol Res 149:29

86. Ridker PM, Everett BM, Pradhan A, MacFadyen JG, Solomon $\mathrm{DH}$, Zaharris E et al (2019) Low-dose methotrexate for the prevention of atherosclerotic events. N Engl J Med 380:752-762
87. Tardif JC, Kouz S, Waters DD, Bertrand OF, Diaz R, Maggioni AP et al (2019) Efficacy and safety of low-dose colchicine after myocardial infarction. N Engl J Med 381:2497-2505

88. Nidorf SM, Fiolet ATL, Mosterd A, Eikelboom JW, Schut A, Opstal TSJ, The SHK, Xu XF, Ireland MA, Lenderink T, Latchem D, Hoogslag P, Jerzewski A, Nierop P, Whelan A, Hendriks R, Swart H, Schaap J, Kuijper AFM, van Hessen MWJ, Saklani P, Tan I, Thompson AG, Morton A, Judkins C, Bax WA, Dirksen M, Alings M, Hankey GJ, Budgeon CA, Tijssen JGP, Cornel JH, Thompson PL (2020) LoDoCo2 trial investigators. Colchicine in patients with chronic coronary disease. N Engl J Med 383(19):1838-1847. https://doi.org/10.1056/NEJMoa2021372

89. O’Donoghue ML, Braunwald E, White HD, Lukas MA, Tarka E, Steg PG et al (2014) Effect of darapladib on major coronary events after an acute coronary syndrome: the SOLID-TIMI 52 randomized clinical trial. JAMA 312:1006-1015

90. O'Donoghue ML, Glaser R, Cavender MA, Aylward PE, Bonaca MP, Budaj A et al (2016) Effect of losmapimod on cardiovascular outcomes in patients hospitalized with acute myocardial infarction: a randomized clinical trial. JAMA 315:1591-1599

91. Tardif JC, McMurray JJ, Klug E, Small R, Schumi J, Choi J et al (2008) Effects of succinobucol (AGI-1067) after an acute coronary syndrome: a randomised, double-blind, placebo-controlled trial. Lancet 371:1761-1768

92. Nicholls SJ, Kastelein JJ, Schwartz GG, Bash D, Rosenson RS, Cavender MA et al (2014) Varespladib and cardiovascular events in patients with an acute coronary syndrome: the VISTA-16 randomized clinical trial. JAMA 311:252-262

Publisher's Note Springer Nature remains neutral with regard to jurisdictional claims in published maps and institutional affiliations. 